\title{
COMPARATIVE WOOD ANATOMICAL PROPERTIES OF GENUS SYZYGIUM (FAMILY MYRTACEAE) FROM MANIPUR, INDIA
}

\author{
Mahesh Wangkhem, Madhubala Sharma* and Chaman L. Sharma \\ Department of Forestry, North Eastern Regional Institute of Science \& Technology, \\ Nirjuli -791109, Itanagar, Arunachal Pradesh, India
}

Received: 19 February 2020, Revised: 20 April 2020, Accepted: 21 April 2020

COMPARATIVE WOOD ANATOMICAL PROPERTIES OF GENUS SYZYGIUM (FAMILY MYRTACEAE) FROM MANIPUR, INDIA. Syzygium belongs to family Myrtaceae and comprises of mostly trees and a few shrubs. This paper studies the anatomical and physical characteristics of five Syaygium species, namely Syzygium cumini, Syaygium fruticosum, Sysygium jambos, Sysygium nervosum and Syaygium praecox and to see intra and inter-species variation among them. The wood samples were taken at breast-height from straight bole and uniform crowned trees. The present study showed that all the selected species shared common features like simple perforation plate, vestured inter-vessel pits, disjunctive ray parenchyma cells, diffuse, diffuse-in-aggregate, vasicentric, aliform and confluent types of axial parenchyma, diffuse-porous and indistinct fruticosum were observed. The vessels were mostly barrel-shaped with small or long tails at one or both ends in all species except tube-shaped in $S$. jambos and drum-shaped in S. fruticosum. Spiral thickenings were present in the tails of $S$. nervosum and $S$. fruticosum. Fibres were thin-walled and non-septate. Occasional septate fibres and vasicentric tracheids were present in $S$. nervosum and $S$. jambos. Crystals in the ray of $S$. nervosum and $S$. fruticosum and silica bodies in axial parenchyma of $S$. jambos were observed. The fibre percentage and wood density were maximum in $S$. jambos, whereas moisture content was minimum in $S$. jambos. Principal Component Analysis revealed a close relationship among all species. Therefore, the qualitative characteristics and all quantitative anatomical characteristics can be used for reliable identification of Syzygium species.

Keywords: Syaygium species, anatomical characteristics, wood density, moisture content

PERBANDINGAN KARAKTERISTIK ANATOMI KAYU GENUS SYZYGIUM (FAMILY MYRTACEAE) YANG BERASAL DARI MANIPUR, INDIA. Sysygium merupakan Family Myrtaceae yang sebagian besar terdiri dari pohon dan semak. Tujuan penelitian ini adalah untuk mempelajari karakteristik. anatomi dan sifat fisik dari lima spesies Sysygium, yaitu Syzygium cumini, Syzygium fruticosum, Syzygium jambos, Syzygium nervosum, dan Syzygium praecox dan untuk melihat variasi intra dan antar spesies. Contoh uji diambil dari batang lurus setinggi dada dengan kondisi pohon yang bertajuk relatif seragam. Hasil penelitian menunjukean bahwa karakteristik anatomi semua spesies yang dipelajari berciri relatif sama, yaitu bidang perforasi sederbana, noktah antar-pembuluh berumbai, sel parenkim jari-jari disjungtif, difus, difus-in-agregat, vasicentric, aliform dan konfluen aksial parenkima, difus porus dan frusicosum tidak jelas. Pembuluh sebagian besar berbentuk silinder dengan ekor kecil atau panjang di satu atan kedua ujungnya di semua spesies kecuali berbentuk tabung di $\underline{\mathrm{S}}$ jambos dan berbentuk silinder di $\underline{\mathrm{S}}$. fruticosum. Penebalan spiral dijumpai di bagian ekor $\underline{\mathrm{S}}$ nervosum dan $\underline{\mathrm{S}}$. fruticosum. Serat berdinding tipis dan tidak bersekat. Serabut bersekat sesekali dijumpai pada trakeid vasicentricjenis $\underline{\mathrm{S}}$. nervosum dan $\underline{\mathrm{S}}$ jambos. Sel kristal dalam jari-jari dijumpai pada jenis $\underline{\mathrm{S}}$. nervosum dan $\underline{\mathrm{S}}$. fruticosum dan badan silika di parenkima aksial jenis $\underline{\mathrm{S}}$ jambos. Persentase serat dan kepadatan kayu paling besar tercatat di $\underline{\mathrm{S}}$.jambos, sedangkan kadar air minimum tercatat di contoh uji $\underline{\mathrm{S}}$. jambos. Analisis komponen utama mengungkapkan hubungan yang erat di antara semua jenis. Oleh karena itu, karakteristik kualitatif bersama dengan karakteristik anatomi kuantitatif dapat digunakan sebagai dasar identifikasi jenis Sysygium.

Kata kunci: spesies Sysygium, karakteristik anatomi, kepadatan kayu, kadar air

*Corresponding author: mbs_madhu@yahoo.co.in 


\section{INTRODUCTION}

The word Syaygium is derived from a Greek word "syzgios" which means the presence of "paired/coupled" branches and leaves (Janick $\&$ Paull, 2008). It is one of the most abundant genera in family Myrtaceae with 1200 species. It is distributed from Africa eastwards to the Hawaiian Island, India, Southern China southwards to Australia and New Zealand (Parnell et al., 2007; Govaerts et al., 2008; A hmad et al., 2016; Christenhusz et al., 2017). It ranks on $16^{\text {th }}$ position among the 57 most abundant genera of flowering plants (Govaerts et al., 2018). Most of the workers have considered both Sysygium and Eugenia under genus Eugenia (Henderson, 1949) as there is no distinction between their morphological characters. Ingle and Dadswell (1953) divided Eugenia into two sections based on anatomical structure 'Eugenia $\mathrm{A}$ ' is comprised of the species having similarity with the new world species and 'Eugenia B' has Sysygium and other Eugenia species which are similar in their anatomy. The timbers of Eugenia A are characterized by the presence of vasicentric tracheids, solitary pores, apotracheal parenchyma, vessel ray pitting small and similar to inter vessel pits. The timbers of Eugenia B are characterized by absence of vasicentric tracheids, presence of multiple pores, paratracheal parenchyma, simple to scalariform vessel ray pitting. This grouping was also supported by Chattaway (1959) who observed substantial differences in bark structure between two groups. The separation of Eugenia and Sysygium as different lineage by Schimid (1972) is further confirmed with molecular studies by several workers (Wilson et al., 2001, 2005; Biffin et al., 2010).

In India, Genus Syzygium is represented by 91 species, of which most are trees and few shrubs (Arisdason \& Lakshminarasimhan, 2017). Sysygium aromaticum is the essential spices with high commercial value. Species like Syzygium cumini, Sysygium jambos are being cultivated in several parts of India for their fruits. From timber point of view, Syaygium cumini is the most important species. Several other species like S. calophyllifolium, S. cerasoides, S. cavaran, $S$. densiflorum, $S$. grande etc. also have good timber value and are being used for construction, furniture, flooring, telegraph poles, side props in mine shafts and galleries, railway sleepers, bottom boards of railway carriages, implements, packaging case, fibreboard, and veneer and plywood.

The anatomical characteristics of wood are valuable storehouse for environmental studies (Fonti et al., 2010) to determine additional and new ecological information and to see the relationship between tree growth and environmental factors. They also help to resolve taxonomical problems to separate the different species. Since there is no information on wood anatomical characteristics of selected Syzygium species, therefore, the present study was carried out (a) to study anatomical and physical features of Syzygium species and (b) to study intra- and inter-species variation in these characteristics.

\section{MATERIAL AND METHOD}

\section{A. Study Site}

Five straight trees with uniform crown and no visible defects of each species were randomly selected from Kakching and Imphal West districts of Manipur, India. The geographical coordinates, height and diameter of selected species were given in (Table 1).

\section{B. Methods}

Wood samples of $5 \mathrm{~cm} \times 5 \mathrm{~cm} \times 4 \mathrm{~cm}$ size at breast height were taken. The wood samples were packed in polythene bags and brought to the laboratory for further processing. Collected samples were cut into small blocks of $2 \mathrm{~cm}^{3}$ size. They were fixed in FAA (Formalin-acetoalcohol) for 24-48 hrs and preserved in 50\% alcohol for anatomical studies. These blocks were cut in 3 planes namely Cross Section (C. S.), Tangential Longitudinal Section (T. L. S.) and Radial Longitudinal Section (R. L. S.) with the help of a sliding microtome (Leica SM 2000R). Standard methods were followed to prepare permanent slides. 
Table 1. List of Sysygium species collected from different sites of Manipur

\begin{tabular}{lcccl}
\hline \multicolumn{1}{c}{ Species } & Latitude \& Longitude & $\begin{array}{c}\text { Height } \\
(\mathrm{m})\end{array}$ & $\begin{array}{c}\text { Diameter } \\
(\mathrm{cm})\end{array}$ & \multicolumn{1}{c}{ Locality } \\
\hline S. cumini & $24^{\circ} 29.938^{\prime} \mathrm{N}-24^{\circ} 47.829^{\prime} \mathrm{N}$ & $5.2-8$ & $32.48-38.85$ & $\begin{array}{l}\text { Mahadevching, Kakching } \\
\text { Sagolband, Imphal west }\end{array}$ \\
& $93^{\circ} 58.084^{\prime} \mathrm{E}-93^{\circ} 55.463^{\prime} \mathrm{E}$ & & & Mahadevching, Kakching \\
S. fruticosum & $24^{\circ} 29.664^{\prime} \mathrm{N}-24^{\circ} 29.679^{\prime} \mathrm{N}$ & $6.5-9.8$ & $36-49$ & \\
& $93^{\circ} 57.860^{\prime} \mathrm{E}-93^{\circ} 57.795^{\prime} \mathrm{E}$ & & & \\
S. jambos & $24^{\circ} 30.107^{\prime} \mathrm{N}-24^{\circ} 30.329^{\prime} \mathrm{N}$ & $4.9-8.4$ & $13.69-15.29$ & Chumnang, Kakching \\
& $93^{\circ} 58.737^{\prime} \mathrm{E}-93^{\circ} 58.384^{\prime} \mathrm{E}$ & & & \\
S. nervosum & $24^{\circ} 43^{\prime} 12^{\prime}{ }^{\prime} \mathrm{N}-24^{\circ} 44^{\prime} 09^{\prime} \mathrm{N}$ & $5.5-6.1$ & $19.41-38.83$ & Lilong chajing, Imphal \\
& $93^{\circ} 55^{\prime} 47^{\prime \prime} \mathrm{E}-93^{\circ} 54^{\prime} 49^{\prime \prime} \mathrm{E}$ & & & \\
S. praecox & $24^{\circ} 29.938^{\prime} \mathrm{N}-24^{\circ} 30.784^{\prime} \mathrm{N}$ & $5.8-7$ & $19.10-23.57$ & Ashram ching, Kakching \\
& $93^{\circ} 58.074^{\prime} \mathrm{E}-93^{\circ} 58.116^{\prime} \mathrm{E}$ & & &
\end{tabular}

Thin matchstick-size of wood was taken from the radial side of each sample of selected species and was macerated with Franklin's solution at $60^{\circ} \mathrm{C}$ for 24 hours till they become soft and white. The macerated material was washed with distilled water 2-3 times and gently shaken to get a fluffy mass of fibres. 2-3 drops of safranine were added, and temporary slides were prepared by using $50 \%$ glycerol. The dimensions of anatomical parameters of vessels, fibres and rays were taken with the help of Scopeimage 9.0 software at different magnifications. For each sample of selected species, 30 random fibres, vessels and rays were chosen for measurement of their various parameters. Ten fields per sample of each species were randomly selected for counting the number of vessels per $\mathrm{mm}^{2}$ and ray per $\mathrm{mm}$ in cross-section. Thus, a total of 250 fields were observed for both parameters. Fibre, vessel, parenchyma and ray proportion were determined on cross-section by selecting ten fields.

The anatomical descriptions of species were given by following IAWA list of microscopic features for hardwoods identification (Wheeler et al., 1989). Different vessel shapes were identified as given by Helmling et al. (2018). The photomicrographs of selected species were taken with the help of image analysis system at different magnifications for their anatomical features.
Water displacement method (Smith, 1955) was used to determine the wood density. Moisture content was determined, as mentioned by Panshin and deZeeuw (1980).

\section{Analysis}

The data were statistically analysed by using SPSS 16 software. One way ANOVA followed by Tukey's test was performed to compare the differences in anatomical characteristics among species.

\section{III.RESULT AND DISCUSSION}

\section{A. Syzygium cumini (L.) Skeels. \\ (Figure 1A-1F; Figure 6A-6D)}

General features - Indistinct heartwood and sapwood; wood colour ranges from pale grey or greyish brown in the outermost region to dark brown or reddish-brown towards the centre; wood is moderately hard to hard and moderately dense to heavy; grain generally shallowly interlocked, sometimes wavy; medium to coarse-textured.

Anatomical features - A semi-ring porous, diffuse-porous wood.

Growth rings - Both distinct and indistinct.

Vessels - Mostly solitary in radial multiple of $2-4$, circular in outline, barrel shape without the tail, with very long or small tail at one and/ or both ends, $500-1200 \mu \mathrm{m}(868.83 \pm 147.66$ $\mu \mathrm{m})$ in length, 105.77-193.69 $\mu \mathrm{m}$ (146.02 \pm $17.18 \mu \mathrm{m})$ in diameter, vessel frequency 6-20 


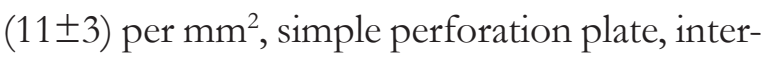
vessel pit alternate, vestured, small to medium $6.87-9.62 \mu \mathrm{m}(8.2 \pm 0.6 \mu \mathrm{m})$ in size, vessel ray pits with much reduce borders to apparently simple: pits horizontal (scalariform, gash like) to vertical (palisade), tyloses present, vessel percentage $17.45 \%$.

Fibres - Thin-walled, 1050-2300 $\mu \mathrm{m}$ $(1766.83 \pm 222.13 \mu \mathrm{m})$ long, 18.28-35.89 $\mu \mathrm{m}(25.13 \pm 3.64 \mu \mathrm{m})$ and 11.08-28.05 $\mu \mathrm{m}$ $(18.62 \pm 3.32 \mu \mathrm{m})$ in diameter and lumen diameter, $2.19-6.37 \mu \mathrm{m}(3.26 \pm 0.66 \mu \mathrm{m})$ in wall thickness, fibre percentage $40.36 \%$.

Parenchyma - Mostly scanty, diffuse, diffusein-aggregate and confluent, parenchyma strand 4-12 cells, vestured pits present, parenchyma percentage $14.55 \%$.
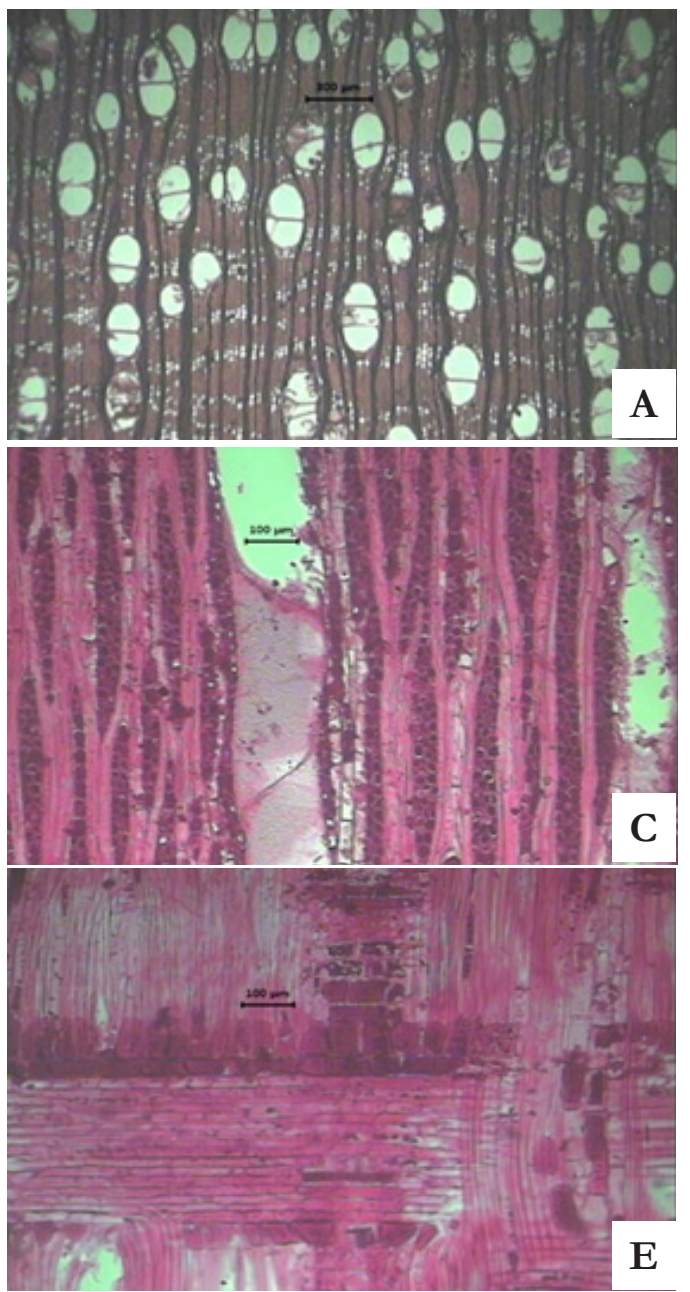

Ray - Uniseriate, biseriate and multiseriate, mean ray height and ray width 352.52-944.07 $\mu \mathrm{m}(632.08 \pm 120.59 \mu \mathrm{m})$ and $30-77.56 \mu \mathrm{m}$ (49.98 $\pm 8.79 \mu \mathrm{m}), 1-3$ cells wide, rays both homocellular and heterocellular, all homocellular rays of upright/square cells, heterocellular rays of body ray cells procumbent with one row of upright and/or marginal square cells, rays 5-10 $(8 \pm 2)$ per $\mathrm{mm}$, disjunctive ray parenchyma cells present, ray percentage $27.64 \%$.

\section{B. Syzygium fruticosum DC.}

(Figure 2A-2F; Figure 6E-6H)

General features - Indistinct heartwood and sapwood, wood pale grey to reddish-brown, moderately hard and moderately heavy; wavy rarely straight grain.
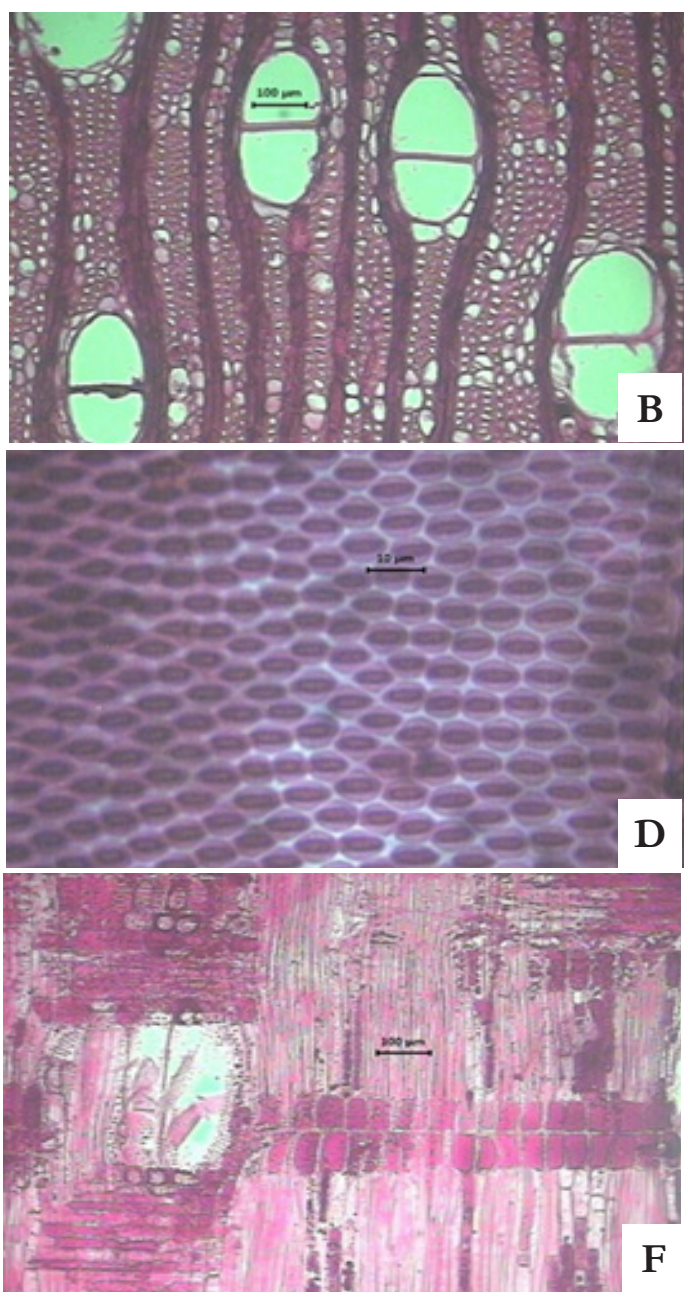

Figure 1. Syzygium cumini: C. S. - Wood diffuse-porous, parenchyma diffuse and confluent type (A \& B); T. L. S. - Rays uniseriate, biseriate and multiseriate (C), vestured intervessel pits (D); R. L. S. - Heterocellular ray of procumbent and upright and/or marginal square cells (E); homocellular ray of upright/square cells (F) 
Anatomical features - A semi-ring porous, diffuse-porous wood.

Growth rings - Both distinct and indistinct.

Vessels - Mostly solitary in radial multiple of 2-4, oval in outline, drum and tube shape with spiral thickening in small and pointed tails, 275-925 $\mu \mathrm{m}(526.50 \pm 124.327 \mu \mathrm{m})$ in length, 63.19-152.47 $\mu \mathrm{m}(113.76 \pm 17.63 \mu \mathrm{m})$ in diameter, vessel frequency 6-10 (13 \pm 3$)$ per $\mathrm{mm}^{2}$, simple perforation plate, inter-vessel pit alternate, vestured, small to medium 7.83-10.85 $\mu \mathrm{m}(9.30 \pm 0.67 \mu \mathrm{m})$ in size, vessel ray pits with much reduce border to apparently simple pits horizontal (scalariform, gash like) to vertical
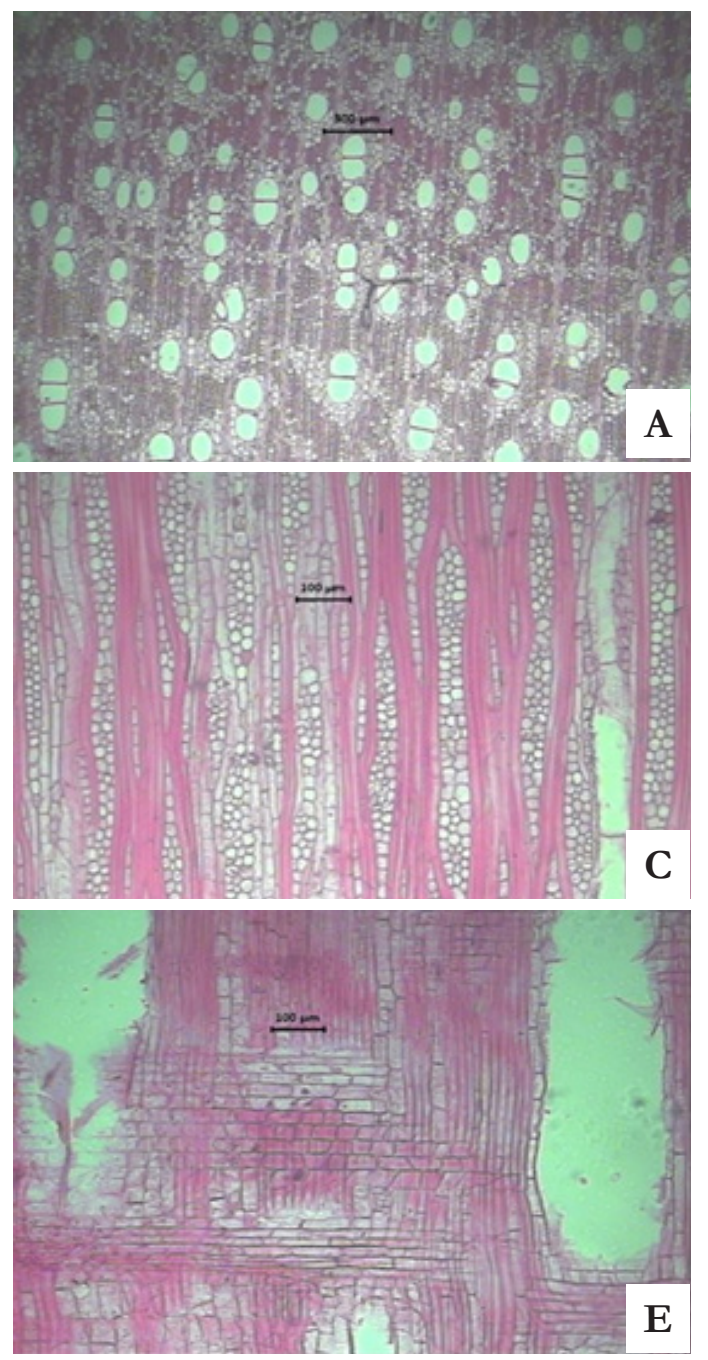

(palisade), tyloses present, vessel percentage $22.91 \%$.

Fibres - Thin-walled, 900-1875 $\mu \mathrm{m}$ $(1286.83 \pm 186.96 \mu \mathrm{m}) \quad$ long, 15.66-34.34 $\mu \mathrm{m}(23.30 \pm 3.04 \mu \mathrm{m})$ and 10.44-27.61 $\mu \mathrm{m}$ $(16.66 \pm 2.65 \mu \mathrm{m})$ in diameter and lumen diameter, 2.06-5.22 $\mu \mathrm{m}(3.32 \pm 0.61 \mu \mathrm{m})$ in wall thickness, septate fibres present, fibre percentage $30.91 \%$.

Parenchyma - Diffuse, diffuse-in-aggregate, aliform and confluent, parenchyma strand 4-12 cells, bordered pits present, parenchyma percentage $29.09 \%$.
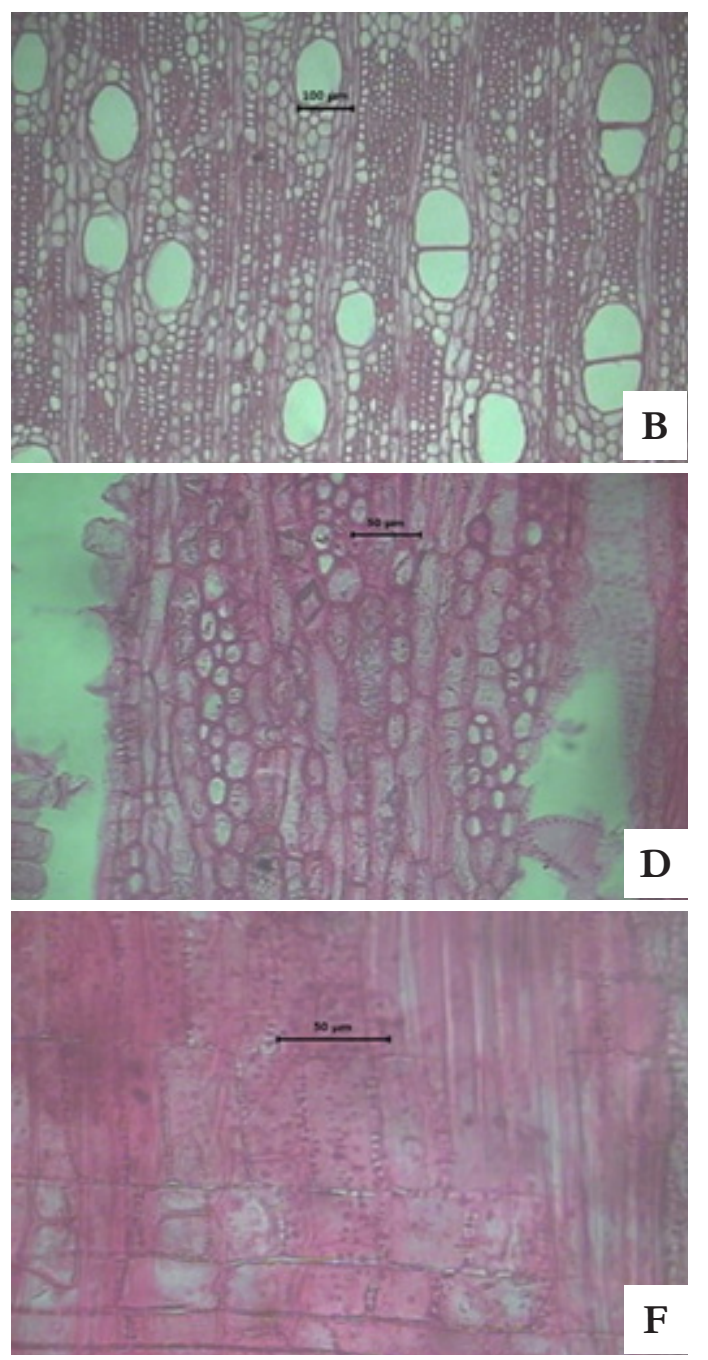

Figure 2. Sysygium fruticosum: C. S. - Wood diffuse-porous, vessels mostly solitary in radial multiple of $2-4$, parenchyma diffuse, diffuse-in-aggregate, confluent type (A \& B); T. L. S. - Rays multiseriate, parenchyma strand 4-12 celled (C), crystals in ray and parenchyma cell (D); R. L. S. - Heterocellular ray of procumbent and upright and/or marginal square cells (E); Disjunctive ray parenchyma cell walls $(\mathrm{F})$ 
Ray - Mostly multiseriate, mean ray height and

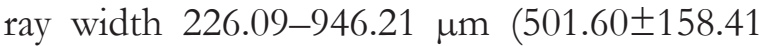
$\mu \mathrm{m})$ and $28.02-68.90 \mu \mathrm{m}(47.71 \pm 8.28 \mu \mathrm{m})$, 1-3 cells wide, rays both homocellular and heterocellular, all homocellular rays of square cells, heterocellular rays are consisting of body ray cells procumbent with 2-4 rows of upright and/or marginal square cells, rays 4-11 (7士2) per $\mathrm{mm}$, disjunctive ray parenchyma cells present, ray percentage $17.09 \%$.

Mineral inclusions - Crystals and crystal sand present in ray and parenchyma, black streaks present among fibres.
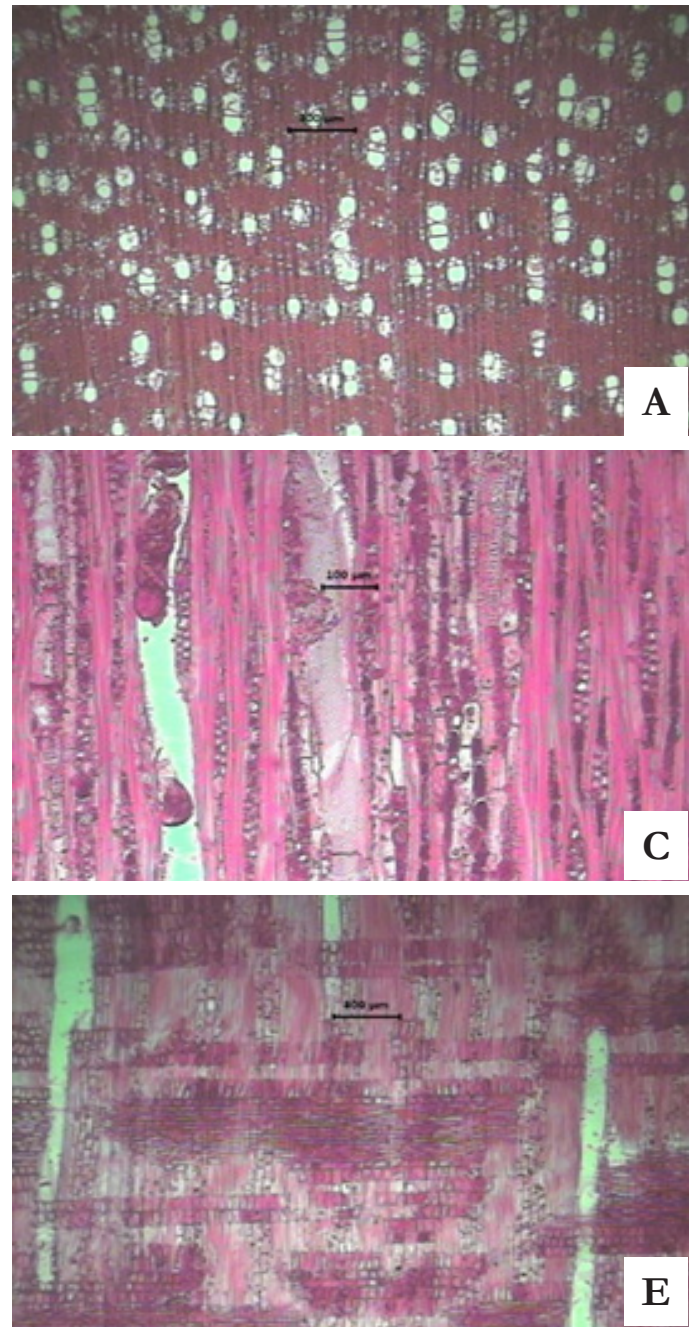

\section{Syzygium jambos (L.) Alston}

(Figure 3A-3F; Figure 6I-6L)

General features - Indistinct heartwood and sapwood, reddish grey to brown, wood slightly soft, moderately heavy, with a reasonably regular wavy grain.

Anatomical features - A diffuse-porous wood.

Growth rings - Both distinct and indistinct.

Vessels - Mostly solitary in radial multiple of $2-4$, clusters, circular in outline, tube shape with short/long tail at one or both ends, $475-1700 \mu \mathrm{m}$ $(892 \pm 186.66 \mu \mathrm{m})$ in length, 61.81-105.78 $\mu \mathrm{m}$ $(83.85 \pm 8.62 \mu \mathrm{m})$ in diameter, vessel frequency


Figure 3. Sysygium jambos: C. S. - Wood diffuse-porous, vessels mostly solitary in radial multiple of 2-4 Parenchyma diffuse, diffuse-in-aggregate, aliform type (A \& B); T. L. S. - Rays multiseriate, tyloses parenchyma strand 2-13 celled (C); R.L.S. - Vessel-ray pits with much-reduced border to simple pits rounded (D); heterocellular rays of procumbent and upright and/or marginal square cells $(\mathrm{E})$, silica bodies in axial parenchyma cells $(\mathrm{F})$ 


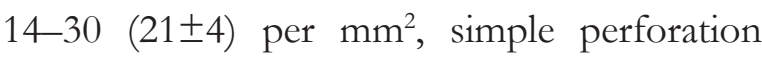
plate, inter-vessel pit alternate, vestured, smallmedium $6.87-8.93 \mu \mathrm{m}(7.72 \pm 0.45 \mu \mathrm{m})$ in size, vessel ray pits with much reduce borders to apparently simple: pits rounded, tyloses present, vessel percentage $14.91 \%$.

Fibres - Thin - thick-walled, 1175-2425 $\mu \mathrm{m}(1657.83 \pm 237.30 \mu \mathrm{m})$ long, 17.52-28.81 $\mu \mathrm{m} \quad(22.20 \pm 2.06 \mu \mathrm{m})$ and $7.20-17.35 \mu \mathrm{m}$ $(11.62 \pm 1.82 \mu \mathrm{m})$ in diameter and lumen diameter, $3.35-7.92 \mu \mathrm{m}(5.29 \pm 1.02 \mu \mathrm{m})$ in wall thickness, vascicentric tracheid present, fibre percentage $44 \%$.

Parenchyma - Diffuse, diffuse-in-aggregate, aliform, confluent and banded, parenchyma strand 4-12 cells, parenchyma percentage $20.36 \%$.

Ray - Uniseriate and biseriate, mean ray height and ray width $369.16-870.23 \mu \mathrm{m}(574.13 \pm 106.07$ $\mu \mathrm{m})$ and 33.08-56.90 $\mu \mathrm{m}(40.11 \pm 4.44 \mu \mathrm{m})$, 1-3 cells wide, rays both homocellular and heterocellular. Homocellular rays of upright and/or square cells, heterocellular rays consisting of body ray cells procumbent with 1-2 rows of upright and/or marginal square

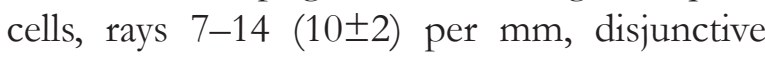
ray parenchyma cells present, ray percentage $20.73 \%$.

Mineral inclusions - Silica bodies present in the parenchyma.

\section{Syzygium nervosum DC. (Figure 4A-4F; Figure 6M-6P)}

General features - Indistinct heartwood, wood reddish grey, hard, rough; moderately heavy heavy; wavy grain to reasonably straight grain.

Anatomical features - A diffuse-porous wood.

Growth rings - Indistinct.

Vessels - Mostly solitary, in radial multiple of 2-3, circular in outline, barrel-shaped without and with spiral thickenings in very long/ small tails at one or both ends, 375-825 $\mu \mathrm{m}$ $(557.67 \pm 114.29 \mu \mathrm{m})$ in length, 103.02-181.32 $\mu \mathrm{m}(135.15 \pm 16.42 \mu \mathrm{m})$ in diameter, vessel

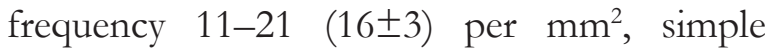
perforation plate, inter-vessel pit alternate and also scalariform, vestured, small-medium $7.08-10.27 \mu \mathrm{m}(8.82 \pm 0.65 \mu \mathrm{m})$ in size, vessel ray pits with much reduce borders to simple: pits rounded, tyloses present, vessel percentage $20.36 \%$.

Fibres - Thin-walled, 1025-1850 $\mu \mathrm{m}$ $(1404.83 \pm 150.88 \mu \mathrm{m}) \quad$ long, 18.85-36.05 $\mu \mathrm{m} \quad(24.04 \pm 3.21 \mu \mathrm{m})$ and $12.19-27.79 \mu \mathrm{m}$ $(17.91 \pm 2.96 \mu \mathrm{m})$ in diameter and lumen diameter, $2.21-4.50 \mu \mathrm{m}(3.07 \pm 0.47 \mu \mathrm{m})$ in wall thickness, septate fibres present, fibre percentage $38.91 \%$.

Parenchyma - Scanty, vasicentric, diffuse, diffuse-in-aggregate and aliform, parenchyma strands 2-13 cells, vestured pits present in the parenchyma, parenchyma percentage $21.82 \%$.

Ray - Multiseriate, mean ray height and ray

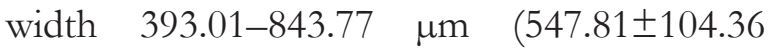
$\mu \mathrm{m})$ and $30.34-71.48 \mu \mathrm{m}(46.84 \pm 8.53 \mu \mathrm{m})$, rays both homocellular and heterocellular, all homocellular rays of square cells, heterocellular rays consisting of body ray cells of procumbent with one row of upright and/or marginal

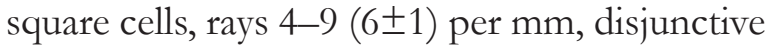
ray parenchyma cells present, ray percentage $18.91 \%$.

Mineral inclusions - Crystal in fibre and parenchyma, black streaks present among fibres.

\section{E. Syzygium praecox (Roxb.) Rathakr. \& N.C.Nair (Figure 5A-5F; Figure 6Q-6T)}

General features - Heartwood and sapwood not clearly demarcated, wood pale grey or greyish brown in the outermost region and gradually grading into dark brown or reddishbrown towards the centre, moderately hard to hard and moderately heavy to heavy, usually interlocked sometimes wavy grains.

Anatomical features - A diffuse-porous wood.

Growth rings - Indistinct.

Vessels - Mostly solitary in radial multiple of 2-4, oval or circular in outline, barrel-shaped without and with very long or small tail at one or both ends, 325-975 $\mu \mathrm{m}(652.50 \pm 134.23 \mu \mathrm{m})$ in length, 61.81-204.67 $\mu \mathrm{m}(112.58 \pm 29.89 \mu \mathrm{m})$ in diameter, vessel frequency 10-22 (15 \pm 3$)$ per 

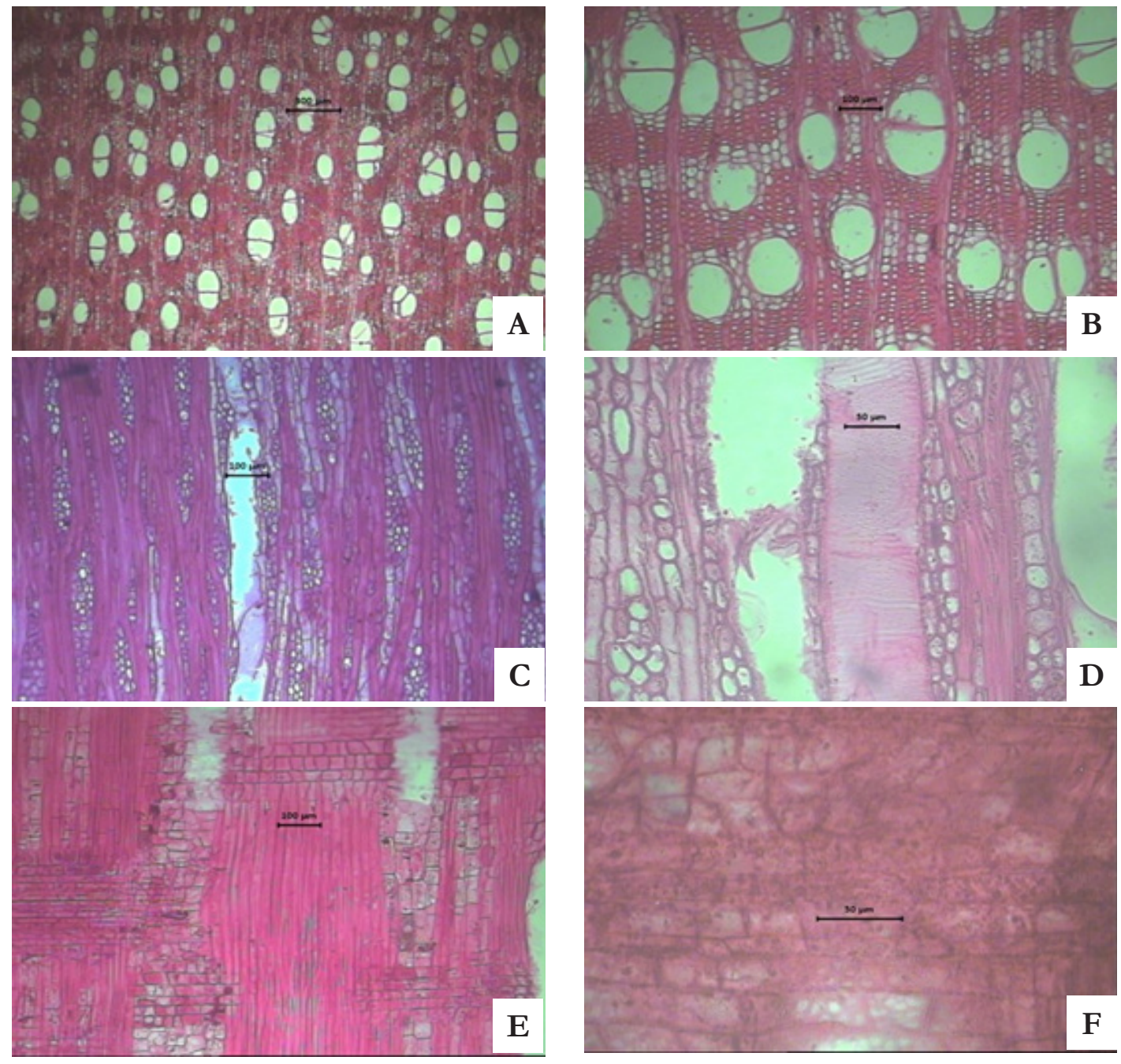

Figure 4. Sysygium nervosum: C. S. - Wood diffuse-porous, vessels mostly solitary and in radial multiple of 2-3, banded Parenchyma (A \& B); T. L. S. - Rays uniseriate, biseriate and multiseriate; parenchyma strand 2-13 celled, crystals in fibre and parenchyma cells (C); scalariform vestured intervessel pits (D); R. L. S. - With a homocellular ray of square cells and heterocellular rays of procumbent body ray cells with 1 row of upright and/or marginal square cells, the crystal in fibre and parenchyma cells (E) and Vessel-ray pits with much-reduced border to simple pits rounded pits (F)

$\mathrm{mm}^{2}$, simple perforation plate, inter-vessel pit alternate, vestured, small-medium 6.05-8.79 $\mu \mathrm{m}(7.61 \pm 0.51 \mu \mathrm{m})$ in size, vessel ray pits with much reduce borders to apparently simple: pits rounded, tyloses present, vessel percentage $16.73 \%$.

Fibres - Thin-walled, 975-1875 $\mu \mathrm{m}$ $(1362.5 \pm 179.5 \mu \mathrm{m})$ long, 16.07-26.59 $\mu \mathrm{m}$ $(20.76 \pm 2.07 \mu \mathrm{m})$ and 10.53-19.39 $\mu \mathrm{m}$ $(14.39 \pm 1.95 \mu \mathrm{m})$ in diameter and lumen diameter, 1.99-4.76 $\mu \mathrm{m}(3.18 \pm 0.64 \mu \mathrm{m})$ in wall thickness, fibre percentage $38.36 \%$.
Parenchyma - Diffuse, diffuse-in-aggregate, vasicentric, confluent and banded, 4-16 cells per parenchyma strand, vestured pits present in the parenchyma, parenchyma percentage $26.55 \%$.

Ray - Uniseriate, biseriate and multiseriate, mean ray height and ray width $348.60-737.42$ $\mu \mathrm{m}(533.75 \pm 80.13 \mu \mathrm{m})$ and $25.03-52.36 \mu \mathrm{m}$ $(36.46 \pm 5.45 \mu \mathrm{m})$, rays both homocellular and heterocellular, all homocellular rays of upright and/or square cells, heterocellular rays consisting of body ray cells procumbent with 

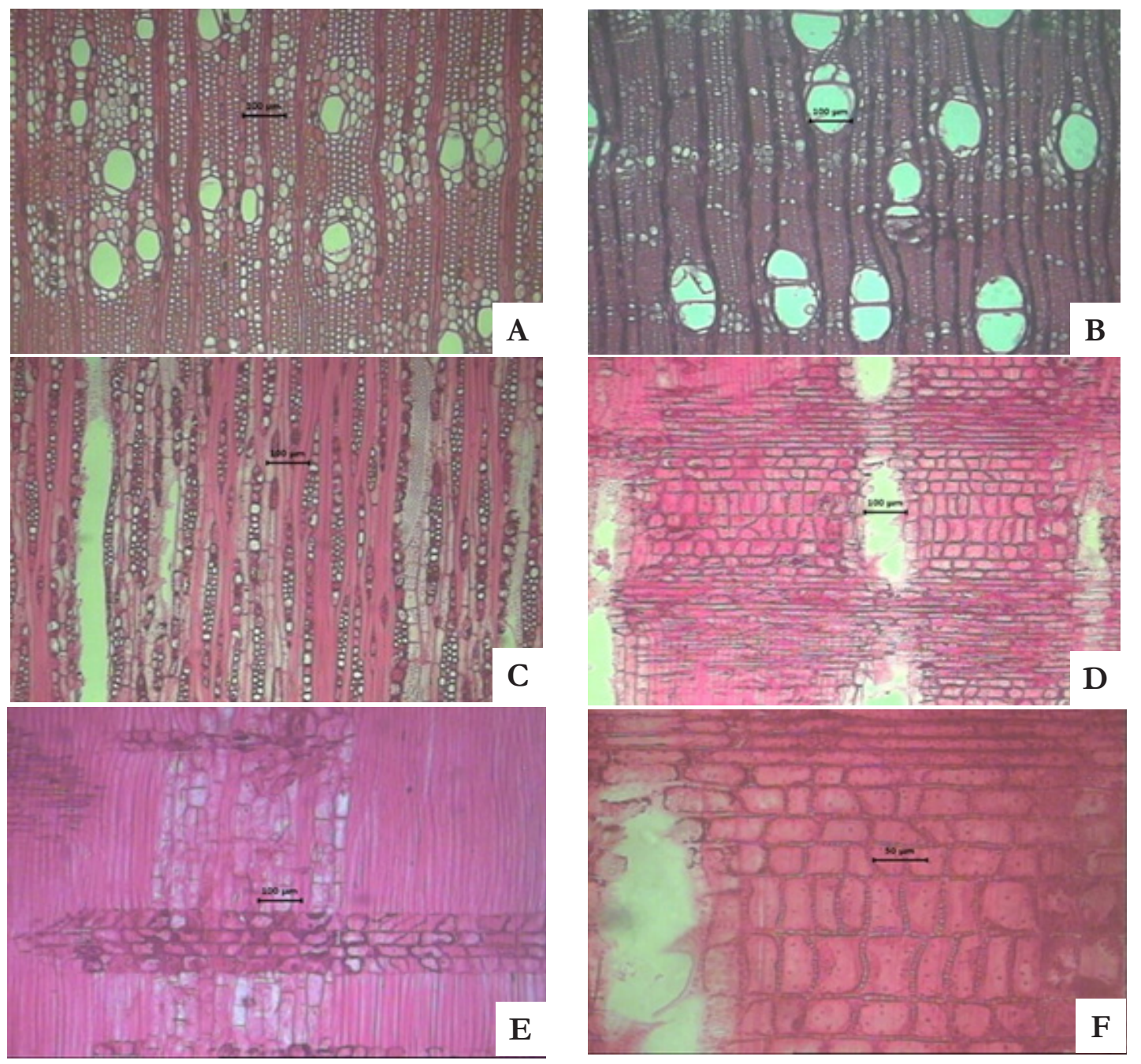

Figure 5. Sysygium praecox: C. S. - Wood diffuse-porous, vessels mostly solitary and in radial multiple of 2-4, diffuse, diffuse-in-aggregate and confluent type of parenchyma (A \& B); T. L. S. - Rays uniseriate, biseriate and multiseriate, parenchyma strand 4-16 celled (C); R. L. S. - Heterocellular ray with procumbent square and upright cells mixed throughout the ray (D), a homocellular ray of upright and/or square cells (E); disjunctive ray parenchyma cell walls (F)

mostly 2-4 rows of upright and/or marginal

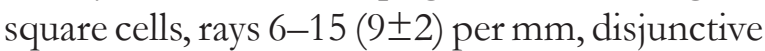
ray parenchyma cells present, ray percentage $18.18 \%$.

The results given in Table 2 show that the anatomical parameters exhibiting significant variation within species were vessel diameter in $S$. cumini and $S$. jambos, vessel length and vessel frequency in $S$. nervosum, fibre wall thickness in $S$. cumini, fibre diameter in $S$. jambos, fibre lumen diameter, ray height and width in $S$. praecox, number of cells in parenchyma strand and ray per $\mathrm{mm}$ in all species.
The vessel, fibre and ray characteristics exhibited significant variation among species except for several cells in parenchyma strand. Vessels were significantly longer in S. cumini and $S$.jambos than other species. Vessel diameter was substantially larger in $S$. cumini whereas intervessel pits were larger in S. fruticosum. Vessel frequency was significantly more in $S$. jambos than other species. Fibre length, fibre diameter and fibre lumen diameter were substantially higher in S. cumini, and fibre wall thickness was more in S. jambos than other species. Ray heights were significantly longer in S. cumini and 

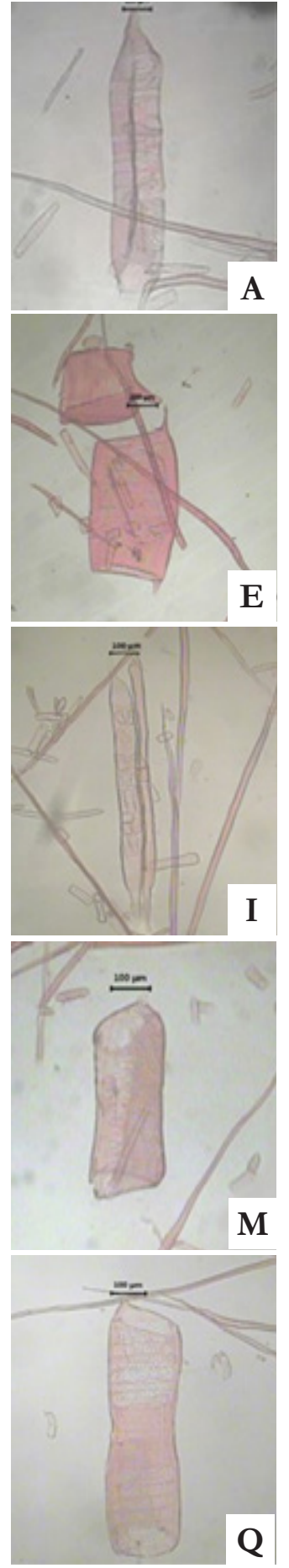

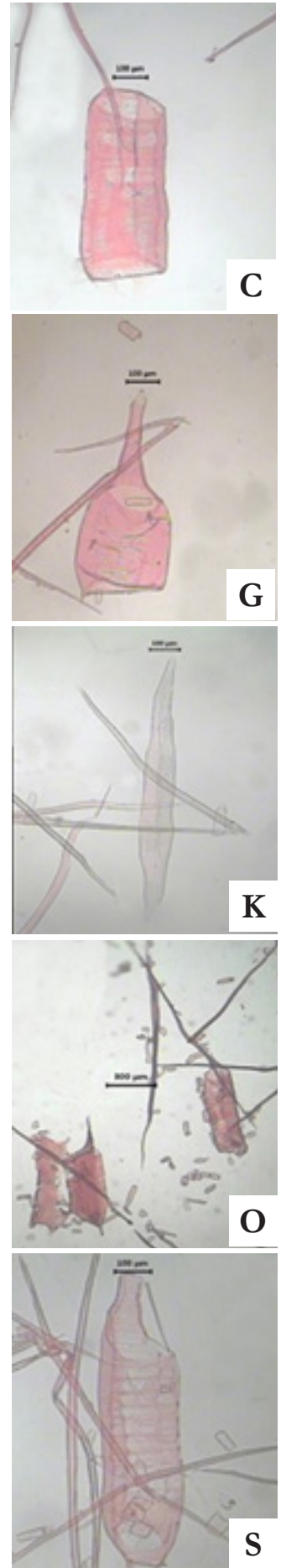
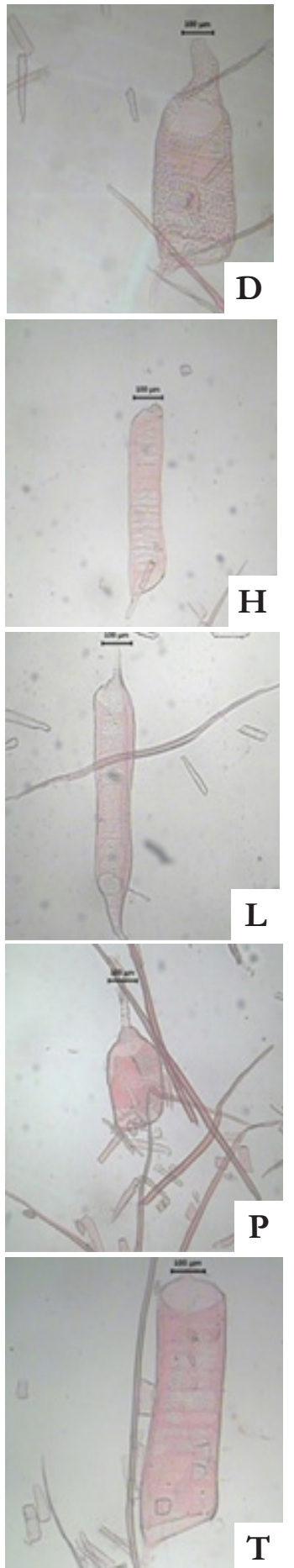

Figure 6. Vessel elements shape: Sysygium cumini - Tube shaped (A), barrel-shaped with and without tails (B - D); Sysygium fruticosum - Barrel-shaped with a small and pointed tail (E - F), spiral thickenings in the tail $(\mathrm{G})$, tube-shaped $(\mathrm{H})$; Sysygium jambos - Vasicentric tracheid with the vessel (I), tube-shaped vessels $(\mathrm{J}$ - L); Syyygium nervosum - Barrel-shaped with small, pointed and long-tail (M - O), spiral thickenings in the tail (P); Sysygium praecox- Barrel-shaped vessels with a small and long-tail (Q - T) 
Table 2. Analysis of variance of anatomical characteristics within the selected Sysygium species

\begin{tabular}{lllcll}
\hline Parameters & $\begin{array}{l}\text { Sysygium } \\
\text { cumini }\end{array}$ & $\begin{array}{l}\text { Sysygium } \\
\text { fruticosum }\end{array}$ & $\begin{array}{c}\text { Sysygium } \\
\text { jambos } \\
\text { (F value) }\end{array}$ & $\begin{array}{l}\text { Sysygium } \\
\text { nervosum }\end{array}$ & $\begin{array}{l}\text { Sysygium } \\
\text { praecox }\end{array}$ \\
\hline Vessel length & $8.809^{* *}$ & $13.337^{* *}$ & $7.405^{* *}$ & $2.216^{\mathrm{ns}}$ & $26.323^{* *}$ \\
Vessel diameter & $2.003^{\mathrm{ns}}$ & $22.055^{* *}$ & $2.268^{\mathrm{ns}}$ & $18.078^{* *}$ & $115.225^{* *}$ \\
Vessel frequency & $3.706^{*}$ & $15.869^{* *}$ & $3.282^{*}$ & $1.220^{\mathrm{ns}}$ & $5.025^{* *}$ \\
Inter vessel pit size & $28.636^{*}$ & $5.866^{* *}$ & $2.259^{\mathrm{ns}}$ & $10.014^{* *}$ & $7.774^{* *}$ \\
Fibre length & $3.465^{*}$ & $14.768^{* *}$ & $16.208^{* *}$ & $2.773^{*}$ & $20.630^{*}$ \\
Fibre diameter & $13.921^{* *}$ & $7.397^{* *}$ & $1.248^{\mathrm{ns}}$ & $8.726^{* *}$ & $4.649^{* *}$ \\
Fibre lumen diameter & $15.550^{* *}$ & $11.003^{* *}$ & $8.098^{* *}$ & $6.276^{* *}$ & $1.193^{\mathrm{ns}}$ \\
Fibre wall thickness & $1.249^{\mathrm{ns}}$ & $5.571^{* *}$ & $16.253^{* *}$ & $9.777^{* *}$ & $24.789^{* *}$ \\
Ray height & $8.397^{* *}$ & $16.364^{* *}$ & $13.622^{* *}$ & $3.847^{* *}$ & $1.424^{\mathrm{ns}}$ \\
Ray width & $15.196^{* *}$ & $11.799^{* *}$ & $3.707^{*}$ & $36.183^{* *}$ & $15.811^{* *}$ \\
Ray frequency & $1.911^{\mathrm{ns}}$ & $2.122^{\mathrm{ns}}$ & $1.826^{\mathrm{ns}}$ & $0.785^{\mathrm{ns}}$ & $4.986^{* *}$ \\
\hline
\end{tabular}

Remarks: The levels of significance used are: $\mathrm{ns}=$ Not-significant, ${ }^{*}=$ Significant at $\mathrm{P} \leq 0.05$ level, ${ }^{* *}=$ Highly significant at $\mathrm{P} \leq$ 0.01 level

Table 3. Anatomical characteristics variation among Sysygium species

\begin{tabular}{|c|c|c|c|c|c|}
\hline \multirow[t]{2}{*}{ Parameters } & Syzygium cumini & $\begin{array}{l}\text { Syzygium } \\
\text { fruticosum }\end{array}$ & & $\begin{array}{l}\text { Syzygium } \\
\text { nervosum }\end{array}$ & Sysygium praecox \\
\hline & \multicolumn{5}{|c|}{$($ Mean \pm SD) } \\
\hline $\begin{array}{l}\text { Vessel length } \\
(\mu \mathrm{m})\end{array}$ & $868.83 \pm 147.66^{c}$ & $526.50 \pm 124.327^{a}$ & $892.00 \pm 186.66^{c}$ & $557.67 \pm 114.29^{a}$ & $652.50 \pm 134.23^{b}$ \\
\hline $\begin{array}{l}\text { Vessel diameter } \\
(\mu \mathrm{m})\end{array}$ & $146.02 \pm 17.18^{\mathrm{d}}$ & $113.76 \pm 17.63^{\mathrm{b}}$ & $83.85 \pm 8.62^{\mathrm{a}}$ & $135.15 \pm 16.42^{c}$ & $112.58 \pm 29.89^{\mathrm{b}}$ \\
\hline $\begin{array}{l}\text { Inter vessel pit } \\
\text { size }(\mu \mathrm{m})\end{array}$ & $8.20 \pm 0.60^{\mathrm{b}}$ & $9.30 \pm 0.67^{\mathrm{d}}$ & $7.72 \pm 0.45^{\mathrm{a}}$ & $8.82 \pm 0.65^{c}$ & $7.61 \pm 0.51^{\mathrm{a}}$ \\
\hline $\begin{array}{l}\text { Vessel frequency } \\
\left(\text { no. } / \mathrm{mm}^{2}\right)\end{array}$ & $11.00 \pm 3.00^{\mathrm{a}}$ & $13.00 \pm 3.00^{\mathrm{a}}$ & $21.00 \pm 4.00^{c}$ & $16.00 \pm 3.00^{\mathrm{b}}$ & $15.00 \pm 3.00^{\mathrm{b}}$ \\
\hline $\begin{array}{l}\text { Fibre length } \\
(\mu \mathrm{m})\end{array}$ & $1766.83 \pm 222.13^{\mathrm{d}}$ & $1286.83 \pm 186.96^{a}$ & $1657.83 \pm 237.30^{c}$ & $1404.83 \pm 150.88^{\mathrm{b}}$ & $1362.50 \pm 179.50^{\mathrm{bc}}$ \\
\hline $\begin{array}{l}\text { Fibre diameter } \\
(\mu \mathrm{m})\end{array}$ & $25.13 \pm 3.64^{\mathrm{d}}$ & $23.30 \pm 3.04^{\mathrm{bc}}$ & $22.20 \pm 2.06^{\mathrm{b}}$ & $24.04 \pm 3.21^{\mathrm{cd}}$ & $20.76 \pm 2.07^{\mathrm{a}}$ \\
\hline $\begin{array}{l}\text { Fibre lumen } \\
\text { diameter }(\mu \mathrm{m})\end{array}$ & $18.62 \pm 3.32^{\mathrm{d}}$ & $16.66 \pm 2.65^{c}$ & $11.62 \pm 1.82^{\mathrm{a}}$ & $17.91 \pm 2.96^{\mathrm{d}}$ & $14.39 \pm 1.95^{\mathrm{b}}$ \\
\hline $\begin{array}{l}\text { Fibre wall } \\
\text { thickness }(\mu \mathrm{m})\end{array}$ & $3.26 \pm 0.66^{a}$ & $3.32 \pm 0.61^{a}$ & $5.29 \pm 1.02^{\mathrm{b}}$ & $3.07 \pm 0.47^{a}$ & $3.18 \pm 0.64^{a}$ \\
\hline Ray height $(\mu \mathrm{m})$ & $632.08 \pm 120.59^{c}$ & $501.60 \pm 158.41^{a}$ & $574.13 \pm 106.07^{\mathrm{b}}$ & $547.81 \pm 104.36^{\mathrm{bc}}$ & $533.75 \pm 80.13^{\mathrm{ab}}$ \\
\hline Ray width $(\mu \mathrm{m})$ & $49.98 \pm 8.79^{\mathrm{d}}$ & $47.71 \pm 8.28^{\mathrm{cd}}$ & $40.11 \pm 4.44^{b}$ & $46.84 \pm 8.53^{c}$ & $36.46 \pm 5.45^{\mathrm{a}}$ \\
\hline Ray frequency & $8 \pm 2^{b}$ & $7 \pm 2^{\mathrm{ab}}$ & $10 \pm 2^{c}$ & $6 \pm 1^{a}$ & $9 \pm 2^{c}$ \\
\hline
\end{tabular}

Remarks: Values with the same letter in the same row are not significantly different at the 0.05 probability level

S. nervosum. On the other hand, S. cumini and $S$. fruticosum had wider rays as compared to other species. The number of rays per mm was higher in $S$. jambos than other species (Table 3).

The maximum fibre percentage was in $S$. jambos (44\%) and the minimum in $S$. fruticosum (30.91\%). Likewise, highest vessel percentage, ray percentage and parenchyma percentage were observed in S. fruticosum (22.91\%), S. cumini $(27.64 \%)$ and S. fruticosum (29.09\%) respectively 


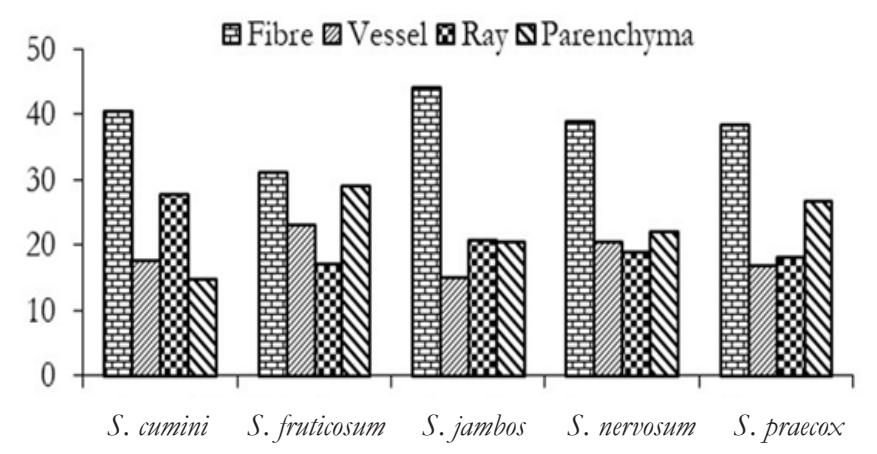

Figure 7. Tissue percentage of the selected Syzygium species

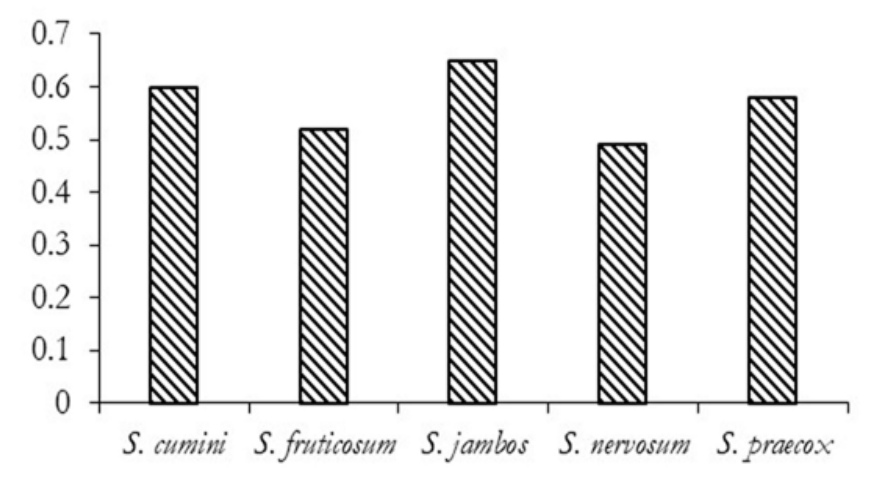

Figure 8. Wood density of selected Sysygium species

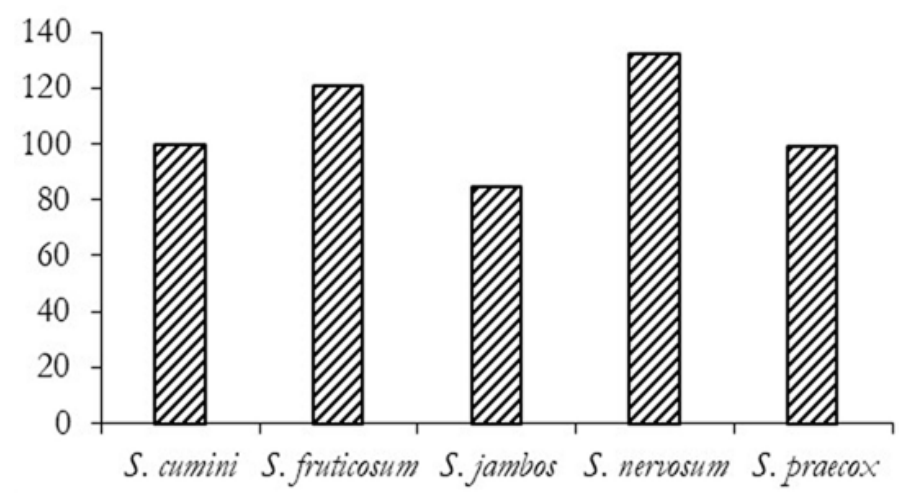

Figure 9. The moisture content of selected Sysygium species

(Figure 7). The results presented in Figure 10 revealed that $S$. cumini was closely related to $S$. praecox. There was a more close relationship between $S$. fruticosum and $S$. nervosum. Though $S$. jambos was also in the same axis, but it forms a separate group.

The result given in Figures 8 showed maximum wood density in $S$. jambos and minimum in $S$. nervosizgum. On the contrary to it, the maximum wood moisture content was in
S. nervosum and minimum in S. jambos (Figure 9). The wood structure in Syzygium species is uniform as reported in other genera of family Myrtaceae (Dias-Leme et al., 1995). All the selected species were diffuse-porous with indistinct rings except both diffuse-porous and semi-ring porous in $S$. cumini and $S$. fruticosum. The vessels were mostly barrel-shaped with small or long tails at one or both ends in all species except tube-shaped in S. jambos and 


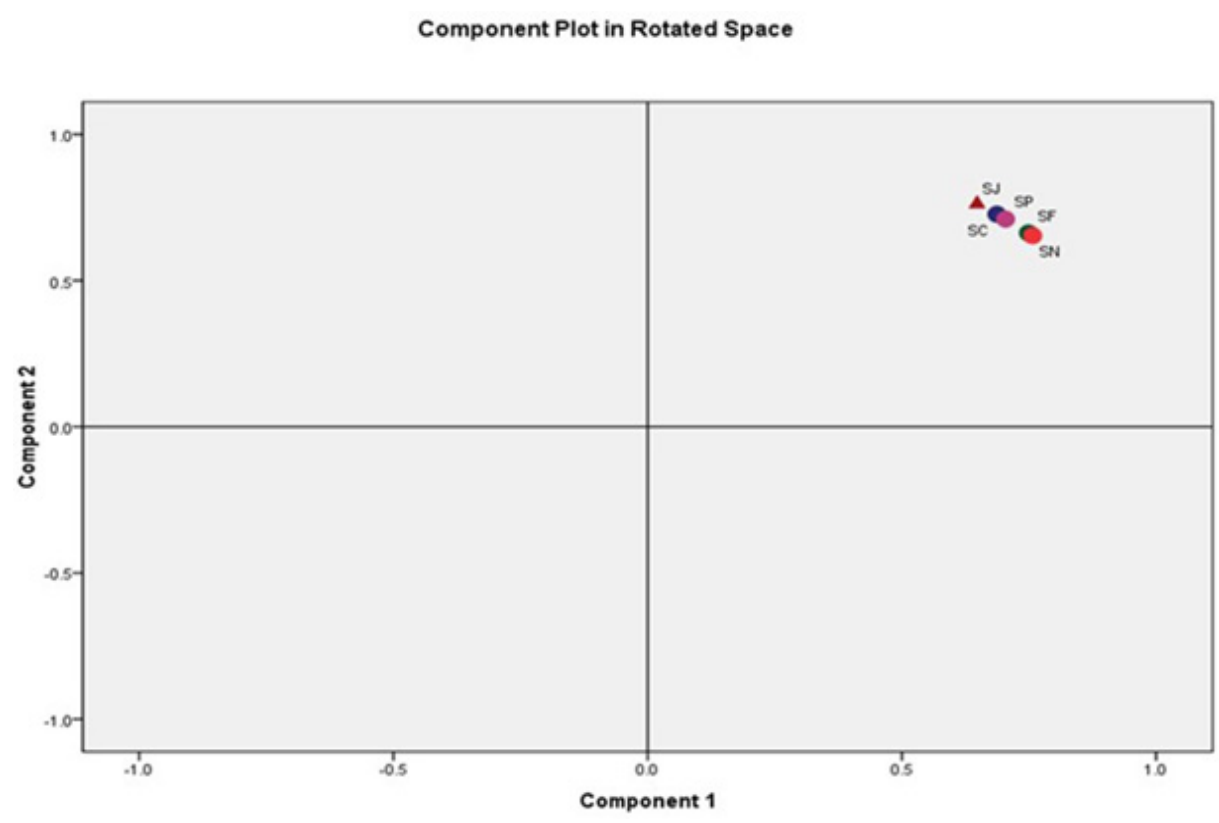

Figure 10. Scattered plot for principal component analysis of selected Sysygium species

drum-shaped in S. fruticosum. Spiral thickenings were present in the tails of $S$. nervosum and $S$. fruticosum. Presence of spiral thickenings in vessel elements and simple perforation plate, small to medium-sized vestured pits and tyloses were common features in all selected species. Similar observations are reported in other genera of family Myrtaceae by Metcalfe and Chalk (1950); Schmid and Baas (1984) and Patel (1995). In S. nervosum, scalariform inter-vessel pits were seen in some parts of vessels which may be due to fusion of adjacent pits.

Fibres were thin-walled and non-septate in all species. Occasional septate fibres and vasicentric tracheids were observed in $S$. nervosum and $S$.jambos. Vasicentric tracheids play an essential role in xylem conduction efficiency and decrease the chances of embolism in vessels (Barotto et al., 2016). The presence of septate fibres in $S$. jambos and $S$. nervosum may be due to presence of less percentage of parenchyma in these species as septate fibres are liable for transportation and also storage of photoassimilates in plants with less parenchyma (Evert, 2006).

The axial parenchyma was diffuse, diffuse in aggregate, vasicentric, aliform and confluent types. Hence, there was no variation in types of axial parenchyma. Vestured bordered pits were seen in $S$. cumini, $S$. fruticosum, $S$. nervosum and $S$. praecox. In the present study, disjunctive ray parenchyma cells were present in all species and corroborated the findings of Patel (1995).

Mineral inclusions are also important features for identification of wood. In the present study, prismatic shaped crystals were found in fibres and axial parenchyma of $S$. nervosum and even in ray and axial parenchyma of $S$. fruticosum. Silica bodies were observed in axial parenchyma of $S$. jambos in radial section. The present investigation is in agreement with the findings of van Vilet and Bass (1984) who reported crystals in genus Lophomyrtus.

Most of the anatomical characteristics existed significant variation within species which may be due to the collection of samples from unknown age of selected trees. On the contrary to it, Pande et al. $(2005,2007)$ reported nonsignificant variation in wood elements within species. The highly significant difference in anatomical parameters among species confirms the findings of other workers (Sharma et al., 2011a, 2011b; Singh et al., 2013) who reported the similar results in other hardwood 
species. Thus, the present study indicates that Sysygium species can be differentiated based on quantitative anatomical characteristics.

The present investigation reveals a close relationship among selected species. Though $S$. jambos was also in the same axis, but it forms a separate cluster. There was a close relationship between $S$. fruticosum - $S$. nervosum and $S$. cumini - $S$. praecox. The present study is in agreement with the findings of Biffin et al. (2006) who reported S. cumini, S. jambos and $S$. nervosum in the same group by using cpDNA sequence from matK and ndhF genes and rpl16 intron.

The wood density and moisture content of Syaygium species showed maximum density and minimum moisture content in $S$. jambos as compared to other species. Higher fibre percentage with thick-walled fibres in $S$. jambos may be the probable reason for its highest density and lowest moisture content.

The identification key for investigated species is given below:

1. Homocellular and heterocellular rays, vessels barrel to tube-shaped without spiral thickenings in tail

1a. Homocellular and heterocellular rays, vessels barrel to tube-shaped without spiral thickenings in tail . .3

2. Vessel diameter more than $100 \mu \mathrm{m}$, vasicentric tracheids and silica bodies absent

2a. Vessel diameter was less than $100 \mu \mathrm{m}$, vasicentric tracheids and silica bodies present S. jambos.

3. Uniseriate, biseriate and multiseriate rays, diffuse, diffuse-in-aggregate and confluent parenchyma, vessel-ray pits horizontal to vertical ---

3a. Uniseriate, biseriate and multiseriate rays, diffuse, diffuse-in-aggregate and confluent parenchyma, vessel-ray pits simple and rounded S.praecox.

4. Multiseriate rays present, aliform, confluent parenchyma and crystals present in rays ......... S. fruticosum. 4a. Multiseriate rays present, vasicentric parenchyma and crystals present in fibres S. nervosum.

\section{IV.CONCLUSION}

The detailed anatomical characteristics of five Sysygium species of Manipur, India revealed that both qualitative features and quantitative anatomical characteristics could be used for identification. Diffuse porous and indistinct growth rings were present in all selected species except Sysygium cumini and Sysygium fruticosum (semi-ring porous and distinct). Vasicentric tracheids were present in Syyygium jambos, and septate fibres were observed in Syzygium nervosum and Syaygium fruticosum. Silica bodies were present in axial parenchyma of Syaygium jambos whereas crystals were observed in the ray of Syzygium nervosum and Syzygium fruticosum. Sysygium jambos had maximum fibre percentage, wood density and minimum moisture content. All the selected species showed significant variations in their quantitative anatomical and physical characteristics. Identification key was prepared for investigated species.

\section{ACKNOWLEDGEMENT}

The authors are thankful to Director, NERIST for providing laboratory facilities.

\section{REFERENCES}

Ahmad, B., Baider, C., Bernardini, B., Biffin, E., Brambach, F., Burslem, D., Byng, J.W. ... Syzygium Working Group. (2016). Syzygium (Myrtaceae): Monographing a taxonomic giant via 22 coordinated regional revisions. PeerJ Preprints 4, e1930v1. doi: //10.7287/ peerj.preprints.1930v1.

Arisdason, W., \& Lakshminarasimhan, P. (2017). Status of plant diversity in India: An overview. Central National Herbarium, botanical survey of India, Howrah. Retrieved from: www.bsienvis.nic.in/Database/Status of Plant Diversity in India 17566.aspx at 1 October 2019. 
Barotto, A. J., Fernandez, M. E., Gyenge, J., Meyra, A., Martinez-Meier, A., \& Monteoliva, S. (2016). First insights into the functional role of vasicentric tracheids and parenchyma in Eucalyptus species with solitary vessels: do they contribute to xylem efficiency or safety?, Tree Physiology, 36(12), 1485-1497. doi://10.1093/treephys/tpw072.

Biffin, E., Craven, L. A., Crisp, M. D., \& Gadek, P. A. (2006). Molecular systematics of Syzygium and allied genera (myrtaceae): evidence from the chloroplast genome. Taxon, 55(1), 79-94. doi:// 10.2307/25065530.

Biffin, E., Lucas, E. J., Craven, L. A., Ribeiro da Costa, I., Harrington, M. G., \& Crisp, M. D. (2010). Evolution of exceptional species richness among lineages of fleshy-fruited Myrtaceae. Annals of Botany, 106(1), 79-93. doi:// 10.1093/aob/mcq088.

Chattaway, M. M. (1959). The anatomy of bark. VII. Species of Eugenia (Sens. lat.). Tropical Woods, 111, 1-14.

Christenhusz, M. J. M., Fay, M. F., \& Chase, M. W. (2017). Plants of the world: An illustrated encyclopedia of vascular plants. Royal Botanic Gardens, Kew: The University of Chicago Press.

Dias-Leme, C. L., Gasson, P., \& Lughadha, E. N. (1995). Wood anatomy of four Myrtaceae genera in the Subtribe Myrciinae from South America. International Association of Wood Anatomists Journal, 16(1), 87-95. doi://10.1163/22941932-90001393.

Evert, R. F. (2006). Esau's plant anatomy. Meristems, cells, and tissues of the plant body: Their structure, function and development. Hoboken, New Jersey: John Wiley \& Sons Inc.

Fonti, P., Von Arx, G., Garcia-Gonzalez, I., Eilmann, B., Sass-Klaassen, U., Gartner, H., \& Eckstein, D. (2010). Studying global change through investigation of the plastic responses of xylem anatomy in tree rings. New Phytologist, 185(1), 42-53. doi: //10.1111/j.1469-8137.2009.03030.x.

Govaerts, R., Sobral, M., Ashton, P., Barrie, F., Holst, B. K., Landrum, L. L. Matsumoto, K., Fernanda Mazine, F., Nic Lughadha, E., Proenca, C., Soares-Silva, L. H., Wilson, P. G., \& Lucas, E. (2008). World checklist of
Myrtaceae. Retrieved from http://wcsp. science.kew.org at 1 October 2019.

Helmling, S., Olbrich, A., Heinz, I., \& Koch, G. (2018). Atlas of vessel elements: Identification of Asian timbers. International Association of Wood Anatomists Journal, 39(3), 250-352.

Henderson, M. R. (1949). The genus Eugenia (Myrtaceae) in Malaya. The gardens' bulletin, Singapore, 12(1), 1-293. Retrieved from https://biodiversitylibrary.org/ page/43612394 at 1 October 2019.

Ingle, H. D., \& Dadswell, H. E. (1953). The anatomy of the timbers of the south-west Pacific area. III. Myrtaceae. Australian Journal of Botany, 1(3), 353-401. doi://10.1071/bt9530353.

Janick, J., \& Paull, R. E. (2008). The encyclopedia of fruit and nuts. United Kingdom: Centre for Agriculture and Bioscience International.

Metcalfe, C. R., \& Chalk, L. (1950). Anatomy of the Dicotyledons. Oxford, UK: Clarendon Press.

Pande, P. K., Negi, K., \& Singh, M. (2005). Intra and Interspecies wood anatomical variation in Balau group of Shorea of the peninsula. Indian Forester, 131(8), 1041-1048.

Pande, P. K., Negi, K., \& Singh, M. (2007). Wood anatomical variations in species of Shorea of balau group of Malay Peninsula - A tool for identification. Indian Forester, 133(6), 759-777.

Panshin, A. J., \& deZeeuw, C. (1980). Textbook of wood technology ( ${ }^{\text {th }}$ edition). New York: McGraw-Hill Series in Forest Resources.

Parnell, J. A. N., Craven, L. A., \& Biffin, E. (2007). Matters of scale: Dealing with one of the largest genera of Angiosperms. Systematics Association Special Volumes, 251-273. doi://10.1201/9781420009538.ch16.

Patel, R. N. (1995). Wood anatomy of the dicotyledons indigenous to New Zealand. 25. Myrtaceae—subfam. Myrtoideae (part I), New Zealand Journal of Botany, 33(4), 541-555. doi:// 10.1080/0028825X.1995.10410625.

Schmid, R. (1972). A resolution of the EugeniaSysygium controversy (Myrtaceae). American Journal of Botany, 59(4), 423-436. doi:10.2307/2441553.

Schmid, R., \& Baas, P. (1984). The occurrence of scalariform perforation plates and helical 
vessel wall thickenings in the wood of Myrtaceae. International Association of Wood Anatomists bulletin new series, 5(3), 197-215. doi:// 10.1163/22941932-90000889.

Sharma, C. L., Sharma, M., Carter, M. J., \& Kharkongor, B. M. (2011a). Interspecies wood variation of Castanopsis species of Meghalaya. Journal of the Indian Academy of Wood Science, 8(2), 124-129. doi: //10.1007/ s13196-012-0031-1.

Sharma, M., Sharma, C. L., Kharkongor, B. M., \& Carter, M. J. (2011b). Wood anatomical variation in some species of Quercus of Meghalaya. Journal of the Indian Academy of Wood Science, 8(2), 152-157. doi:// 10.1007/ s13196-012-0057-4.

Singh, M. K., Sharma, M. B., \& Sharma, C. L. (2013). Wood anatomical variations in some Terminalia species of Assam. International Journal of Botany and Research, 3(2), 13-18. Retrieved from https://www.researchgate. net/publication/235970575_WOOD_ ANATOMICAL_VARIATIONS_IN_ SOME_TERMINALIA_SPECIES_OF_ ASSAM at 1 October 2018.

Smith, D. M. (1955). A comparison of two methods for determining the specific gravity of small samples of secondary growth, Douglas fir. U. S. Forest Products Laboratory Report No. 2033,21. Retrieved from https:// ir.library.oregonstate.edu/concern/ defaults/0z709126j at 1 October 2017. van Vliet, G. J. C. M., \& Baas, P. (1984). Wood anatomy and classification of the Myrtales. Annals of the Missouri Botanical Garden, 71(3), 783-800. doi:// 10.2307/2399162.

Wheeler E.A., Baas P., \& Gasson P.E. (1989). IAWA list of microscopic features for hardwood identification. International Association of Wood Anatomists bulletin new series, 10(3), 219-332.

Wilson, P. G., O’Brien, M. M., Gadek, P. A., \& Quinn, C. J. (2001). Myrtaceae revisited: a reassessment of infrafamilial groups. American Journal of Botany, 88(11), 2013-2025. doi://10.2307/3558428.

Wilson, P. G., O’Brien, M. M., Heslewood, M. M., \& Quinn, C. J. (2005). Relationships within Myrtaceae sensu lato based on a matK phylogeny. Plant Systematics and Evolution, 251(1), 3-19. Retrieved from doi://10.1007/ s00606-004-0162-y at 1 October 2018. 